\title{
EFFECTS OF DROUGHT STRESS ON THE QUALITY OF MAJOR OILSEED CROPS: IMPLICATIONS AND POSSIBLE MITIGATION STRATEGIES - A REVIEW
}

\author{
El SABAGH, A..$^{*}$ - HOSSAIN, A. ${ }^{2}$ - BARUTÇUlAR, C. ${ }^{3}$ - GORMUS, O. ${ }^{3}-$ AHMAD, Z. ${ }^{4}$ - HuSSAIN, S. $^{5}-$ \\ ISLAM, M. S. ${ }^{6}$ - ALHARBY, H. ${ }^{7}-$ BAMAGOOS, A. ${ }^{7}-$ KUMAR, N. ${ }^{8}-$ AKDENIZ, H. $.^{9}-$ FAHAD, S. $^{10}$ \\ MEENA, R. S. ${ }^{11}$ - ABDELHAMID, M. ${ }^{12}$ - WASAYA, A. ${ }^{13}$ - HASANUZZAMAN, M. ${ }^{14}$ - SOROUR, S. $^{1}$ \\ SANEOKA, $\mathrm{H}^{15}$ \\ ${ }^{I}$ Department of Agronomy, Faculty of Agriculture, Kafrelsheikh University, Egypt \\ ${ }^{2}$ Bangladesh Wheat and Maize Research Institute, Dinajpur-5200, Bangladesh \\ ${ }^{3}$ Department of Field Crops, Faculty of Agriculture, University of Cukurova, Adana, Turkey \\ ${ }^{4}$ Department of Life Sciences, The Islamia University of Bahawalpur, Punjab, Pakistan \\ ${ }^{5}$ Department of Agronomy, University of Agriculture, Faisalabad ,38040, Punjab-Pakistan \\ ${ }^{6}$ Department of Agronomy, Hajee Mohammad Danesh Science and Technology University, \\ Basherhat, Bangladesh \\ ${ }^{7}$ Department of Biological Sciences, Faculty of Science, King Abdulaziz University, 21589 \\ Jeddah, Saudi Arabia \\ ${ }^{8}$ ICAR-Indian Institute of Pulses Research, Kanpur, 208024, India \\ ${ }^{9}$ Ĭgdır University, Agricultural Faculty, Department of Field Crops, I $\breve{g} d \imath$-Turkey \\ ${ }^{10}$ University of Swabi, Anbar, District Swabi, Khyber Pakhtunkhwa, Pakistan \\ ${ }^{11}$ Department of Agronomy, Institute of Agricultural Sciences, Banaras Hindu University \\ Varanasi-221005 (UP), India \\ ${ }^{12}$ Botany Department, National Research Centre, 33 Al Behoos Street, Dokki, Cairo, Egypt \\ ${ }^{13}$ College of Agriculture, Bahauddin Zakariya University, Bahadur Campus, Layyah, Pakistan \\ ${ }^{14}$ Department of Agronomy, Faculty of Agriculture, Sher-e-Bangla Agricultural University, \\ Sher-e-Bangla Nagar, Dhaka-1207, Bangladesh \\ ${ }^{15}$ Plant Nutritional Physiology Laboratory, Graduate School of Biosphere Science , Hiroshima \\ University, Hiroshima, Japan \\ *Corresponding author \\ e-mail: ayman.elsabagh@agr.kfs.edu.eg \\ (Received $15^{\text {th }}$ Nov 2018; accepted $12^{\text {th }}$ Feb 2019)
}

\begin{abstract}
Oilseed crops are considered as one of the most essential dietary components in human consumption as well as animal feed. While drought is one of the most important abiotic stress that adversely effect on the yield and nutritional quality of major oilseed crops across the globe. Therefore, maintenance of nutritional quality in such crops under drought stress may offer good opportunities to
\end{abstract}


provide sufficient human food as well as animal feed. The current review is to quantify the adverse effects of drought on the qualitative and quantitative traits of oilseed crops, suggest strategies for enhancing drought tolerance in crops. Although drought stress-induced effects on seed oil quality vary with larger environments as well as crop species and their interactions. When short and long term drought occurs at the seed/grain filling stage of crops, it might negatively influence the grain yield as well as the quality of crops. In the present review, we highlight that there are two ways to mitigate the adverse effect of drought viz., development of crop cultivars tolerant to drought and to follow improved management approaches including the exogenous application of osmoprotectants, essential macro and micronutrient management and using organic amendments (compost, green manures, cow manure and incorporation of crop residues) in soils in order to increase the yield and grain quality of oilseed crops.

Keywords: abiotic stress, crop phenology, oil quality, osmotic stress, plant adaptation, protein content, stress resistance

Abbreviations: ABA, abscisic acid; AC, ash content; APX, ascorbate peroxidase; AsA, ascorbic acid; AY, ash yield; CAT, catalase; chl a, chlorophyll a; chl b, chlorophyll b; CI, conventional irrigation; DSI, drought stress index; DW, dry weight; Exo, exogenous (ly); Exo-GB, exogenous glycine betaine; ExoPro, exogenous proline; Exo-app, exogenous application; Fe, iron; FW, fresh weight; GB, Glycine betaine; GW, grain weight; GY, grain yield; LAA, L-ascorbate; MDA, malondialdehyde; Mg, magnesium; NO, nitric oxide; P, phosphorous; PAL, phenylalanine ammonia lyase; PC, protein content; POD, Peroxidase; Pro, proline; Pri, priming; PY, protein yield; OC, oil content; OSP, osmoprotectants; OY, oil yield; RDF, recommended dose of fertilizers; RLWC, relative leaf water content; ROS, reactive oxygen species; RWC, relative water content; SA, salicylic acid; SC, starch content; Se, selenium; SI, supplemental irrigation; SNP, sodium nitroprusside; SOD, superoxide dismutase; STI, stress tolerance index; SY, starch yield; UV, ultra-violet radiation; Tre, trehalose; TW, test weight; Zn, zinc

\section{Introduction}

The impacts of climate change are the foremost thought in many developing countries, due to greater vulnerabilities and limited ability to mitigate the adverse effect of climate change for sustainable crop production (Ali et al., 2017). The economy of most developing countries is based on agriculture, while agricultural sector is fully depend on nature (IPCC, 2012; Mendelsohn, 2014).

The major abiotic stresses such as drought, salinity, heat stress and water-logging are the main climatic factors for declining crop production in many developing countries (Hossain et al., 2013; Jahan et al., 2019; EL Sabagh et al., 2019b). Among them, drought stress is considered the most important one that adversely effect on the yield and quality of many field crops including oilseeds also (Alqudah et al., 2010), through altering the growth, physiology and metabolic activities of plants (Islam et al., 2011). Growing demand for food, feed and raw materials for industries has stressed upon the production of good quality of agricultural products. It is well established that drought has a directly affect the quality of agricultural crops, however, the severity of the drought on the crop production generally depends on the soil moisture status and nutrients availability (Gandah et al., 2003) as well as crop cultivars (Cooper et al., 1987).

Scientists have been trying to overcome the impacts of environmental stresses including drought by employing different strategies, such as improving stress tolerance in crops through foliar application of plant growth regulators, osmoprotectants (OSP), organic and inorganic nutrients which are efficient, economical and environmentally sound approaches (Ahanger et al., 2017; Yakhin et al., 2017). To counteract drought stress plants synthesize osmolytes and perform osmotic adjustment as a frontier in drought tolerance (Blum, 2016). Hence, the adverse effects of drought stress on the fatty acid composition in oilseed crops are not yet deeply elucidated. Therefore, the current 
review aims to understand the crop responses to drought stress in terms of important quality traits of oilseed crops, as well as to find the appropriate management approaches to enhance stress tolerance in these crops.

\section{Effects of drought on quality of major oilseed crops}

Drought stress leads to reduce the seed quality by producing small and medium-sized seeds; while deteriorating the seed vigour and rate of germination (Alqudah et al., 2010). Fahad et al. (2017) observed that under drought stress, the enzymatic activities of plants are diminished, that eventually lead to decrease the yield and quality of oilseed crops. The reduction in oil content has been observed under water deficient conditions of soybean seed also confirmed by Maclagan (1993). Serraj and Sinclair (2002) revealed that the increasing level of soluble carbohydrate and proline (Pro) content in many drought-induced plant species have been associated with the decrease in the protein content and the increase in proteolytic activation, resulting in an increase in the total soluble nitrogen.

Abiotic stresses such as drought might make changes in oil content and compositions in plants (Bagheri et al., 2012), due to water deficit condition often alters the composition and biosynthesis process of fatty acids leading to the reduction of oil yield and composition (Baldini et al., 2000). While, Amini et al. (2014) found a positive effect of water-deficit stress on seed quality (particularly protein) of oilseed crops. The greater seed quality was associated with the physiological process of the plants under water-deficit conditions. Similarly, Foroud et al. (1993) observed the significant increase of seed protein content in soybean under soil moisture stress. The increased protein and the reduced oil contents in plants were associated with the changes in the embryo, endosperm and testa of the seed (Henry and MacDonald, 1978).

Nevertheless, the underlying mechanisms and the extent of how drought stress affect fatty acids composition in different crop species are under research (Nazari et al., 2017). A details description of the effect of drought (soil moisture stress) on major oilseed crops is described below.

\section{Soybean (Glycine max L.)}

Soybean is considered as an essential oil seed legume crop in the globe, as it provides good quality oils, vegetable protein (Akande et al., 2009; El-Mohsen et al., 2013) and also extraordinary qualities suitable for humans and animals feeding, such as $40-42 \%$ good quality protein and 18-22\% oil (Arshad et al., 2006). Drought is considered as the most important limiting factor reducing seed protein content of soybean (EL Sabagh et al., 2015) (Fig.1), through decreasing photosynthesis (Smiciklas et al., 1992). Drought also altered the composition of fatty acid in soybean, which affected oil content and oil composition (Bellaloui et al., 2013). The fatty acid composition differed when soybean plant was subjected to drought stress, along with a decrease in palmitic, linoleic and linolenic acids, with an increase of stearic and oleic acids were noticed by Gao et al. (2009). Further, drought affects the fatty acid composition, oil stability and oil processing (Gao et al., 2009). The increase of total oil and oleic acid concentrations and a decrease of linoleic and linolenic acid concentrations may be due to water deficit stress altering the rate of oil and fatty acids accumulation by possibly affecting fatty acid desaturations. The water deficit stress during seed filling stage is critical because of the inverse relationship between oil and 
protein with temperature (Carrera et al., 2009). Drought also alters fatty acid composition (Gao et al., 2009) and affects oil stability (Brumm et al., 1990). The effect of drought on seed composition gives an opportunity to breeder and biotechnology researchers to develop drought-tolerant soybeans with stable desirable fatty acid traits.

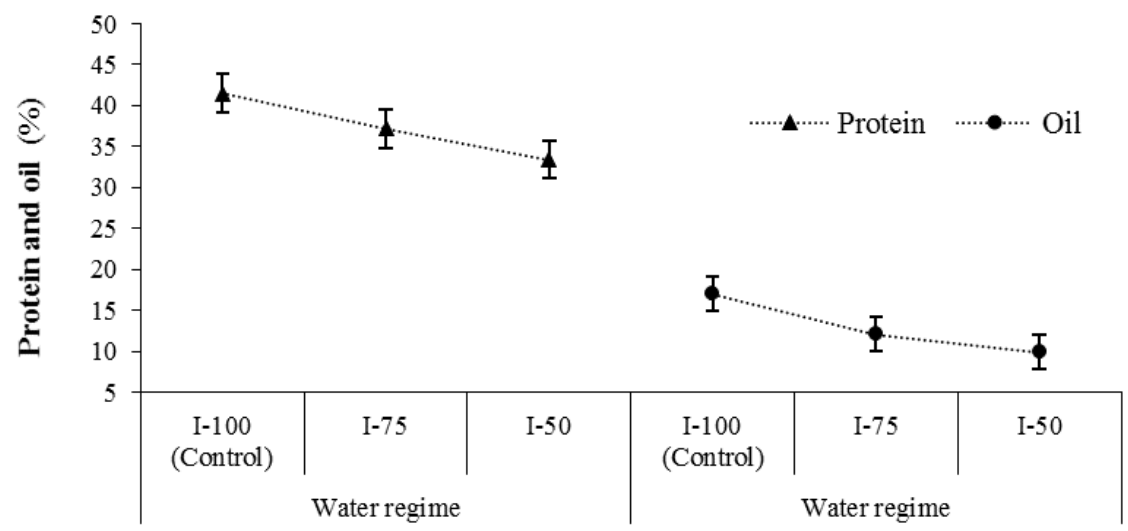

Figure 1. Effects of proline, glycine betaine and compost application on yield traits and quality in soybean under water stress. Bars indicate standard errors. (Source: EL Sabagh et al., 2015)

Protein content in seed depends on genetic and environmental factors, mainly drought through the grain filling stage (Tea et al., 2004). Drought stress during pod filling considerably reduced total protein and nitrogen content in seeds (Ghanbari et al., 2013). Drought stress occurs during critical periods of seed formation and seed filling stages reduced the oil content in seed. The reduction in the oil content under drought stress could be due to the oxidation of some of the polyunsaturated fatty acids (Singh and Sinha, 2005). Nonetheless, plants under drought stress increased protein contents by $2-23 \%$ as compared to unstressed plants (Rotundo and Westgate, 2010). The variations of the results among the investigations were due to the timing and intensity of the drought stress during the different stages (Carrera et al., 2009).

The decrease in oil content in soybean was also reported by Triboi-Blondel and Renard (1999). Whereas, the lowest oil percentage (20.8\%) was obtained under drought stress at the grain filling stage (Smiciklas et al., 1992). Drought stress occurs during critical periods of seed formation and seed filling stages reduced the quantity and quality of seed oil (Maleki et al., 2013). A significant difference among soybean cultivars in terms of oil and protein percentage under drought stress was observed by Mohammadkhani and Heidari (2008). Franklin et al. (2010) also reported that the grain protein remarkably decreased with increasing water stress. The drought had little effect on the fatty acid composition of soybean seed (Dornbos and Mullen, 1992). The drought stress reduced the seed isoflavones in induced soybean plants (Al-Tawaha et al., 2007), while increased alfa-tocopherol concentration in seed (Britz and Kremer, 2002).

Under such situation, oil and protein percentages can be improved by external application of proline (EL Sabagh et al., 2016). Long-term interval of irrigation may build up water shortage in plants which generate organic acid contents in plants body. Boydak (2002) did not find any significant differences between 2-, 6- and 9-day irrigation intervals in the stearic acid content but an increase was observed with 12-day irrigation intervals in soybeans. 


\section{Canola (Brassica campestris L.)}

The most prominent constituents of cell membrane lipids are fatty acids which play a central role in cell permeability under the harsh and normal environment (Sculer et al., 1991). The composition of fatty acids in canola seeds fully depends on polyamines, by controlling the activity of some enzymes synthesis, which play a vital role in fatty acids metabolism (Talaat and EL-Din, 2005). Ullah et al. (2012) found that the basic level of erucic acid was higher in the canola seed and the erucic acid level was increased under drought stress, while another fatty acid such as oleic and linoleic acids and their composition ratio was not altered by drought stress. EL Sabagh et al. $(2015,2016)$ found that drought is one of the limiting factors that significantly influenced the quality parameters of canola. The water deficit condition significantly influenced the oil content and oil yield as well as protein yield of canola seed (EL Sabagh et al., 2017) (Fig. 2).

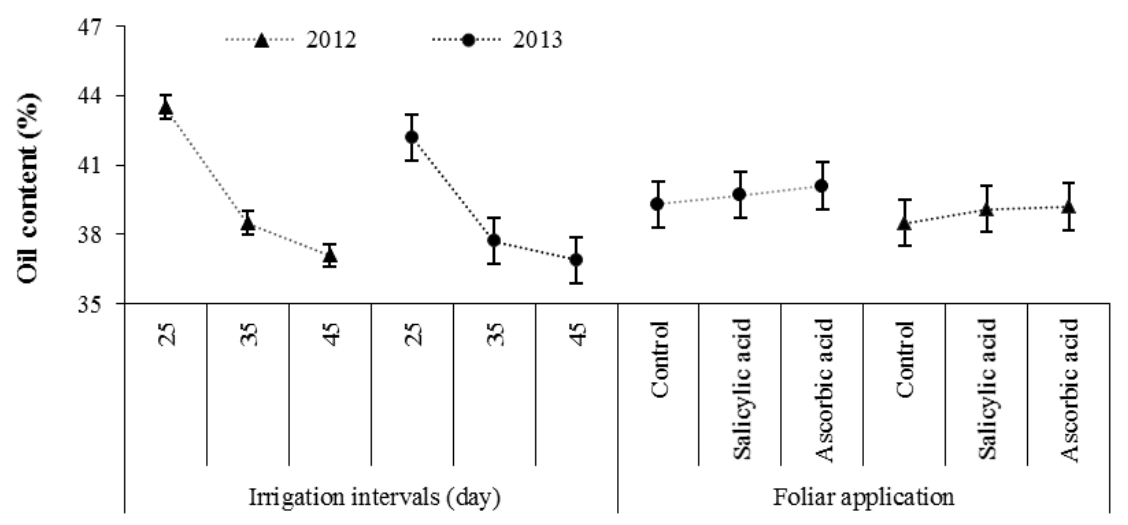

Figure 2. Effect of irrigations intervals and antioxidants applications on the quality traits of canola during 2012 and 2013 seasons (Source: EL Sabagh et al., 2017)

They also reported that irrigation at every 25 days intervals produced the highest values for these parameters followed by irrigation at every 35 days intervals. A similar type of reduction in oil content was also reported by Zhang et al. (2014) under-water deficient conditions, indicating that the reduction of oil contents is a common incident under drought stress. Zahedi et al. (2009) reported that drought stress caused a remarkable reduction in oil percentage, due to the reduction of the photosynthesis and the remobilization of assimilation.

Generally, the agronomic operations have an impact on the growth, yield and quality in different crops under different environmental conditions especially drought condition (Barutçular et al., 2016; Abdelaal et al., 2017; EL Sabagh et al., 2019a). Furthermore, optimum irrigation increases seed oil contents, whereas water deficit condition reduces the oil content of canola, due to the oxidation of some polyunsaturated fatty acids as a result of alteration in the physiological and biochemical activities of affected plants (Singh and Sinha, 2005). Similarly, a decrease in seed yield and deteriorating the seed oil quality of canola under drought conditions was also reported by Moghadam et al. (2011) and Rad and Zandi (2012). Reduction in linoleic acid and oleic content of canola under drought stress was also observed by Pritchard (2007).

Environmental stresses such as drought have significant effects on seed oil fatty acid composition of canola (Dawood and Sadak, 2014). Bouchereau et al. (1996) showed that water stress during the flowering stage affects the oil concentration as well as the 
fatty acid composition of canola seeds. Drought stress increased the percentage of palmitic acid and reduced unsaturated fatty acids (Aslam et al., 2009). In addition, severe drought stress reduced the oleic acid content of canola by $3.8 \%$ in a Mediterranean-type environment (Qaderi et al., 2006). A reduction of $2.0 \%$ in the linoleic content of canola has also been reported in a Mediterranean-type environment under severe soil water stress. This effect on oil production could be due to the oxidation of some fatty acids under drought stress conditions (Singh and Sinha, 2005). Moderate and severe drought stress increased the total saturated fatty acids and decreased the unsaturated fatty acids relative to control plants (Dawood and Sadak, 2014). Tohidi-Moghadam et al. (2011) mentioned that water deficit condition decreased the canola oil and linoleic acid contents, but increased stearic, $\alpha$-linolenic, and gadoleic acids contents. Ullah et al. (2012) stated that drought stress reduced the oil quality of canola by decreasing oleic acid content and increasing the erucic acid content. However, the maximum erucic acid content was observed in the treatment where $60 \%$ irrigation was applied while, the minimum was found at 100\% irrigation level (Ali et al., 2014). The accumulation of glucosinolates in rapeseed under drought stress during flowering stage has been reported by Bouchereau et al. (1996). Drought stress augmented the seed glucosinolates and oil erucic acid (C22:1) content of canola also reported by Ullah et al. (2012). The decrease in total phenolic contents of canola seeds under drought stress is also reported by Dawood and Sadak (2014). While, Gecgel et al. (2007) revealed that the effect of oilseeds genotype on fatty acids was greater than that of the environment stresses.

\section{Sunflower (Helianthus annuus L.)}

Since sunflower has the capability to survive under stress condition than other oilseed crops to some extent, but it is highly sensitive to drought stress from flowering to grain filling stage due to inadequate availability of soil moisture and high ambient temperature in the arid and semi-arid region (Hussain et al., 2018). They also noticed that low soil moisture (water deficit) in combination with high air temperature from flowering to grain filling stages significantly reduced the seed yield and seed oil quality of sunflower. Oraki and Aghaalikhana (2012) noticed that low precipitation (drought stress) in the arid and semi-arid regions in combination with high ambient temperature significantly reduced the oil quality of sunflower through shortening the germination, anthesis and achene filling period, and also suppressing the stem elongation and leaf area (Soleimanzadeh et al., 2010; Babaeian et al., 2011; Fulda et al., 2011). The environmental factors during the seed-filling period can widely affect the oil percentage and fatty acid composition of oil (Anastasi et al., 2010). Drought leads to an increase in the oleic acid content of high oleic acid of hybrids sunflower, but a decrease in ordinary hybrids (reported by Baldini et al., 2000). The increased of linoleic and palmitic acid and decreased of oleic acid and stearic acid contents in sunflower seeds under water stress were also reported by Petcu et al. (2001). Jasso de Rodriguez et al. (2002) stated that the oil content of sunflower seeds showed a slight decrease when drought was occurred during grain filling to harvest time. They also found that water stress caused a significant reduction of oleic acid (about 8-14\%) in a standard hybrid. While Baldini et al. (2002) and Flagella et al. (2000) found that water stress increased the oleic acid content but decreased linoleic acid content in both standard and high oleic content genotypes. The findings of the previous studies related to the adverse effect of drought on the seed and oil quality of sunflower also confirmed by Rondanini et al. (2003) and 
Lacombe et al. (2004), who noticed that under drought stress the composition of saturated fatty acids changed into unsaturated fatty acids. However, the linoleic acid (predominately unsaturated fatty acids) also changed through enzymatic processes governed by genes coding for oleoyl $\Delta-9$ desaturase and oleoyl $\Delta-12$ desaturase. Debaeke et al. (2017) and Hussain et al. (2018) confirmed that nitrogen (N) transport from root to shoot is restricted due to the weak absorbing capacity of the droughtaffected crop which ultimately reduced the yield and oil quality of sunflower.

\section{Flax (Linum usitatissimum L.)}

Flax is well known as linen flax or linseed around the World. It is grown in many countries for fibers as well as oilseeds. As linseeds' oil has been used as the basic component or additive of various paints and/or polymers industries (Shim et al., 2015). Likewise, seeds of flax contain about 36-40\% oleic (omega-6), linoleic and linolenic acids (omega-3) (unsaturated fatty acids), which are very essential poly-unsaturated fatty acids for human beings and also for animals, because these acids cannot synthesize inside the body of both human and animals; thus it should ingest in human and animal diets (El-Beltagi et al., 2007).

However, under water deficit condition, flax plants produce less oil and fibre in comparison to irrigated condition (Bauer et al., 2015). Rashawn et al. (2016) observed a highly significant variation among the three tested flax cultivars of 'Sakha 1', 'Giza 9' and 'Giza 10' regarding protein and oil content under drought stress (Fig. 3). The highest oil yield was also reported at recommended (normal) irrigation, followed by limited irrigation at the stem elongation stage of flax also reported by Mirshekari et al. (2012). Considering on fiber-type flax, higher fiber contents along with the higher straw yield resulted in the high yielding fiber-type cultivars whose fiber yielding capacity is 60-70\% higher than the seed-type cultivars (Bauer et al., 2015). The fiber quality (fineness and length), fiber percentage, overall yield and oil quality were adversely affected by drought (also reported by Abd El-Fatah, 2007; El-Refaey et al., 2010).

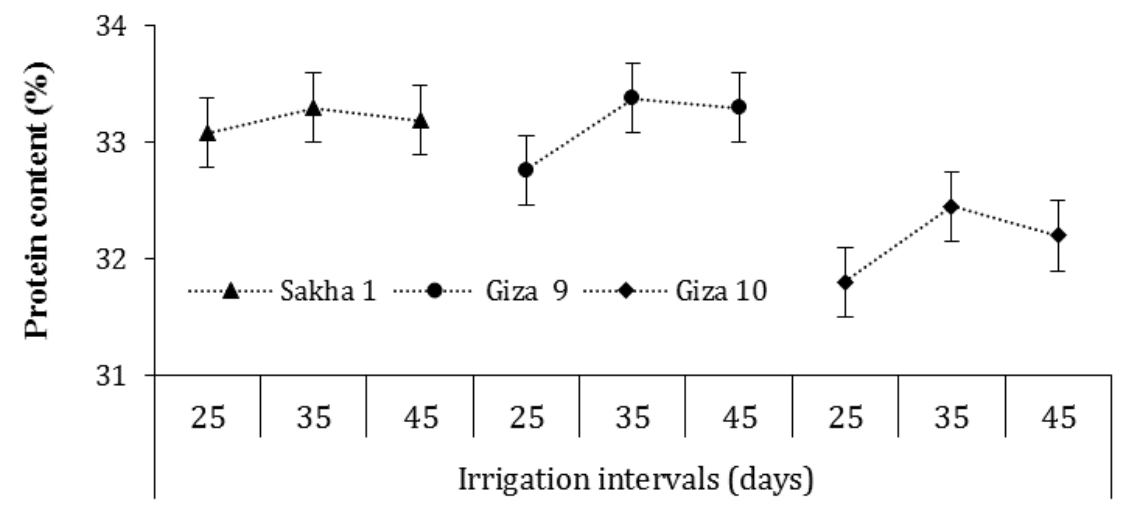

Figure 3. Effects of irrigation intervals and flux cultivars on oil and protein content (Source: Rashawn et al., 2016)

\section{Safflower (Carthamus tinctorius L.)}

Safflower is an essential oilseed crop that can moderately tolerate against several environmental stresses including drought (Mohammadi et al., 2016). While, Amini et al. (2014) and Mohammadi et al. (2018) observed that the environmental conditions and 
management practices affected the oil content of safflower cultivars. Among the environmental stresses, water deficient condition increase protein and decrease oil contents of safflower (Nabipour et al., 2007; Amini et al., 2014). Drought stress during seed filling has been referred to as the major reason for reduced oil content in safflower (Mohammadi et al., 2018).

Ashrafi and Razmjoo (2010) found that safflower oil content was highly affected by different irrigation levels. They also reported that the oil contents of safflower cultivars were significantly reduced under limited irrigation (drought). Similarly, Bagheri and SamDaliri (2011) found a significant reduction of oil content in safflower seeds' as a result of different irrigation regimes, especially with the lack of water during the seedfilling stage.

Generally, seeds' oil of safflower contains a large amount of saturated (palmitic and stearic) and unsaturated (oleic, linoleic and linolenic) fatty acids and composition, which may be affected by abiotic stresses particularly due to drought stress (FernándezCuesta et al., 2014). While, Ensiye and Khorshid (2010) found that drought stress reduced the content of oil and oil composition in the seeds of safflower cultivars, due to a dramatic decrease in saturated fatty acid contents. The oil contents, palmitic, stearic, oleic and linoleic acid contents were reduced under drought during the process of flowering and seed development (also reported by Boydak et al., 2010). Further, drought reduces the palmitic, stearic, oleic and linoleic acid contents (Ashrafi and Razmjoo, 2010). Petcu et al. (2001) also found that the stearic acid content was reduced as drought levels increased. Although the palmitic acid content was decreased, but linoleic acid content was increased up to $14 \%$ under drought stress (Petcu et al., 2001). Higher oleic and linoleic acids and lower stearic and palmitic acids under drought stress were reported by Arslan and Kucuk (2005). Under water-stress, the early maturity of plants get a shorter period of grain filling duration, as well as shorter time for conversion of oleic to linoleic acid. This could be the main reason for linoleic acid ratio reduction under drought-stress condition (Nazari et al., 2017).

\section{Peanut (Arachis hypogaea L.)}

Major factors influencing oil and other composition profile of peanut includes variety/cultivars/species and environmental conditions such as light, temperature, water stress and atmospheric constituents (Pattee, 2005). Chaiyadee et al. (2013) and Gulluoglu et al. (2016) found that genotypes, seasonal variation, location, air and soil temperature, planting date, soil nutrient, moisture availability, growing conditions and maturity affect the fatty acid content in peanut oil. However, under stress conditions, the changes even in the fatty acid composition and the decreasing order of the main fatty acids was in oleic acid, linoleic acid and palmitic acid, respectively (Amir et al., 2005). Other reports indicate that mid-seasonal drought had no effect, while late season drought significantly reduced the total oil and linoleic acid contents, and increased the stearic and oleic acid contents of peanut seeds (Dwivedi et al., 1993). Under water stress conditions, a large reduction in oil and oleic acid content in peanut was observed by Hashim et al. (1993) and also, reduction in linoleic acid, but an increase in oleic acid (Dwivedi et al., 1996).

A reduction in oil content of soybean and groundnut under drought stress were also reported by Dornbos and Mullen (1992) and Dwivedi et al. (1993); while a significant increase in the stearic acid content of peanut seeds under drought stress has been reported by Dwivedi et al. (1993). A reduction of $4-14 \%$ in the oleic content of 
sunflower but an increase in the oleic acid concentration of groundnut under drought stress have also been reported by Petcu et al. (2001). Reddy et al. (2003) observed the application of the different irrigation levels had different responses on the protein content of the seeds of groundnut; while the plants with adequate irrigation water not only gave more kernels but also produced the higher levels of total proteins and oil contents. Dwivedi et al. (1996) pointed out that the total oil and linoleic acid contents of peanuts decreased under water stress during the grain filling stage, but that total protein and stearic acid contents increased under this condition.

\section{Management strategies of drought stress to improve the yield and quality of major oilseed crops}

Plants induce stress tolerance mechanism by engineering/altering primary and secondary metabolites. Pant hormones and other compatible compounds such as carbohydrate, amino acid, polyamine, abscisic acid, phenolic compounds, glucosinolate, carotenoid and terpenoid derivatives, play a vital role to maintain the adaptation of plants through changing their membrane stabilization, osmoregulation, free radical scavenging, reduction of leaf area and leaf abscission, stimulation of root growth, electrolytic leakage etc. A details information related to crop-specific management and their survival mechanism is described under the following sub-headings.

\section{Soybean (Glycine max L.)}

The most significant responses of plants to survive against drought stress are an accumulation of minerals and enhancement to OSP synthesis which are as a part of the metabolic activity of plants to enhance tolerance against drought stress (Samarah et al., 2004). The accumulation of OSP compounds such as Pro assists the stressed cells of plants through water preservation (Hare et al., 1998) and maintain the structure of cell membrane integrity (Conroy et al., 1988). Similarly, Ashraf and Iram (2005) reported that external application of OSP increased the osmotic adjustment in legumes (including soybean) for increasing the survival capacity against water stress. Metabolic changes in response to drought conditions play a significant role in the osmotic adjustment of metabolism and physiology of the soybean varieties to survive under drought stress (Silvente et al., 2012). One approach to increase oxidative stress tolerance in soybean plants on drought stress is the foliar application of exo-antioxidants through improving the total soluble protein, SOD, POD and $\mathrm{H}_{2} \mathrm{O}_{2}$ as compared to control (Hasanah et al., 2017). The increased seed oil and protein content were observed due to foliar application of Pro under water deficit conditions (EL Sabagh et al., 2016). Exogenous application of Pro in drought-affected plants ameliorated the adverse effect through maintaining the osmotic adjustment and altering the metabolic activity under water deficit conditions, thereby maintaining high photosynthetic efficiency and finally increased the quality of seeds (Ali et al., 2007). Ali and Ashraf (2011) stated that exoGB improved the quality of oil by reducing the un-saponifiable matter and improving oil saponification and iodine values, the measure of oil unsaturation. In this concern, EL Sabagh et al. (2016) observed that foliar applied GB improved seed oil and protein content in soybean under water deficit conditions. Compatible solutes like GB or Pro improved the seed quality of soybean as a result of their protective effect on cellular structures during fatty oil biosynthesis and storage, which occurs in liposomes or oleosomes in seeds during the grain-filling stage of the plant (Ali et al., 2013;). 
Similarly, EL Sabagh et al. (2015) also found that foliar application of GB, stimulated the protein content in stress affected plants by improving the osmoprotective impact on the photosynthetic machinery and regulation of ion homeostasis (Hussain et al., 2008). Under drought stress the OSP help to transport essential hormones like cytokinins for biosynthesis and also have a role in the transport of photo-assimilates (Taiz and Zeiger, 2006; EL Sabagh et al., 2015).

However, application of compost is more effective on seed oil content than applying mineral nitrogen. This might be due to the fact that nitrogen composes protoplasmic protein, which required for increasing the growth and then increasing the seed oil content and oil yield. The influence of organic manure by improving the physical structure of the soil and increasing available nitrogen, which reflects a good growth and, consequently, more absorption of nitrogen and more crude protein synthesis (El-Bana, 2000; El-Sadek, 2005). Compost application was more effective mineral nitrogen on seed protein content might be due to the fact that nitrogen composes protoplasmic protein, which required for increasing the growth and then increasing the seed protein content (Connor et al., 2011). Similarly, the relative increase in protein yield by the application of vermicompost as compare to mineral nutrients. Jaleel et al. (2009) indicated that application of vermicompost with inorganic fertilizers improved yield and protein of Phaseolus vulgaris (common bean) seeds.

\section{Canola (Brassica campestris L.)}

Application of antioxidants significantly influenced the protein percentage of canola seed; while non-significant variation was found in terms of the oil content. It was observed that the application of salicylic acid (SA) and ascorbic acid (AsA) in combination with irrigation intervals achieved superior yield of canola, as well as significant increase in protein and oil content of canola (Fig. 4).

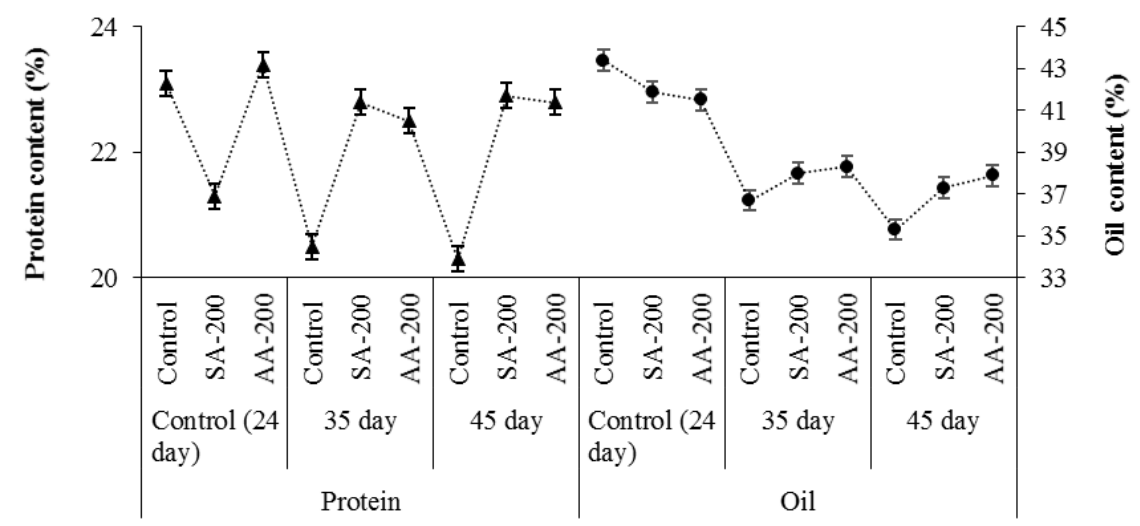

Figure 4. Oil and protein content of canola as affected by the interaction of irrigation intervals and antioxidants applications during 2012 and 2013 seasons. SA, Salicylic acid; AA, Ascorbic acid (Source: EL Sabagh et al., 2017)

Ahmadi et al. (2015) reported that spraying of $300 \mathrm{mg}^{-1}$ ascorbate peroxidase reduced the effect of drought-stressed on rape-seeds. Application of SA in an appreciative rate enhanced the antioxidant ability of cell and generated new protein synthesis in the photosynthetic apparatus (Tirani et al., 2013). According to EL-Tayeb (2005), SA application decreased the stress-induced loss in chlorophyll content and 
photosynthetic rate. AsA can also decrease the harmful result of oxidative stress and enhancing the plant growth under stress environment (Dolatabadian et al., 2009). Application of SA decreased the erucic acid rates in rape oil (Ullah et al., 2012). Application of GB leads to higher carbohydrate contents, oil contents, Pro contents, total soluble sugars and lower concentration of $\mathrm{MDA}$ and $\mathrm{H}_{2} \mathrm{O}_{2}$ under drought stressed in rape plants (Dawood and Sadak, 2014).Similarly, Ali et al. (2013) reported that compatible solutes such as GB or Pro improved the oil quantity and quality, due to their protective effect on cellular structures during fatty oil biosynthesis and storage, which occurs in liposomes or oleosomes in seeds during seed filling stage. Ali (2011) stated that exogenous GB improved the quality of oil by decreasing the un-saponifiable matter and increasing oil saponification and iodine values, the measure of oil unsaturation. Plant growth regulators are important compounds for the rapeseed yield and quality (Huberman et al., 2014). Putrescine, a new plant growth regulator, belonging to polyamines, is reported for its beneficial effects on plant growth under environmental stresses (Perez-Adamor et al., 2002).

\section{Sunflower (Helianthus annuus L.)}

Sunflower plays a vital role in providing a ridiculous source of edible oil and protein for human consumption. However, drought stress severely reduced the growth, development, and yield of sunflower. Therefore, under changing climate particularly in drought stress in arid and semi-arid regions, it is important for the development of drought tolerant genotypes and also adaptive management approaches that are suitable for sustainable sunflower production. There are two ways to mitigate heat stress in crops, either by developing and practising improved stress management practices or by developing and using drought-tolerant cultivars (Farooq et al., 2011; Hossain et al., 2013; Hussain et al., 2018). Since, researchers around the globe have been trying to find-out the adaptive technologies which are appropriate to alleviate the adverse effects of drought (Bowsher et al., 2016; Sourour et al., 2017). Nonetheless, development of drought-tolerant cultivars through breeding programs is highly important for improvement of global sunflower production mainly in dry regions where a major portion of sunflower is cultivated under limited water (Rauf and Sadaqat, 2007; Hussain et al., 2018). The first step for improvement of drought resistance of crops is to assess the genetic variation that exists in wild types. Therefore, evaluation of these target resources in combination with genotyping and phenotyping traits under field conditions are directly related to the improvement in drought tolerance of sunflower (Rauf, 2008; Hussain et al., 2018). Considering phenotyping criteria, leaf area index might be preferred as first priority to identify genotypes under drought stress as it is highly correlated with net assimilation rate (Hemmati and Soleymani, 2014).

On the other hand, several stress tolerance indices (STIs), including stress tolerance, mean productivity, geometric mean productivity and stress susceptibility index, and can be used for identification high-yielding varieties with improved tolerance to stress (Ramirez and Kelly, 1998). These are used to determine stress tolerance in terms of minimizing the reduction in production caused by unfavourable versus favourable environments. STIs are measuring stress tolerance in genotypes by comparing GY under stressed environments (Rauf and Sadaqat, 2007; Hussain et al., 2018).

In case of management approaches, exo-application of phytohormones and OSP such as $\mathrm{ABA}$, potassium chloride, $\mathrm{SA}$ and $\mathrm{CaCl}_{2}$, sodium nitroprusside (SNP) a nitric oxide (NO) donor, triazole compounds, Pro and GB positively improved oil quality of 
sunflower through improving the physiological and biochemical processes of stressinduced plants (Babaeian et al., 2011). Zaidi et al. (2015) reported that foliar spray of SA significantly improved the Pro, sugars and proteins of sunflower under drought condition, indicating that exogenous SA plays an imperative role to survive plant under drought tolerance. Hussain et al. (2014) found that app of ABA at budding or flowering stages of sunflower helped to ameliorate the adverse effects of drought stress. Moreover, Narusaka et al. (2003) reported that ABA app regulates some stress reactive genes $\left(\mathrm{HaACCO}_{2}\right)$ and proteins in sunflower under drought stress. Similarly, Hussain et al. (2018) reported that exogenous ABA application induces the $\mathrm{HaACCO}_{2}$ gene accumulated in leaves of sunflower, which is responsible for drought tolerant in sunflower. While, Rabert et al. (2013) found that triazole compounds like hexaconazole, tebuconazole and propiconazole when applied to sunflower under stress condition partially ameliorated the adverse effects of drought stress through improving the antioxidant enzymes i.e., SOD, APX and CAT activities. Filová (2014) reported that application of 28-homobrassinolide significantly improved the antioxidant enzymes and biochemical traits of sunflower to increase tolerance against drought stress. A sufficient nutrition of plants under stress conditions (including drought) improve tolerance against stress. Ashraf et al. (2015) observed that application of the major nutrients enhances the survival capacity against drought stress by improving protein synthesis, stomatal regulation, homeostasis and osmoregulation through reducing the ROS.

Application of micronutrients enhances sunflower performance against drought stress (Movahhedy-Dehnavy et al., 2009; Zafar et al., 2014) by improving the antioxidant defense, stay green, achenes weight and oil yield. Hussain et al. (2015) and Iqbal et al. (2015) found that exogenous application of $\mathrm{CaCl}_{2}$ has a positive effect on relative leaf water content (RLWC), leaf pigments (such as chlorophyll a, chlorophyll b, carotenoids, anthocyanins, carotenoids), leaf minerals such as $\mathrm{N}, \mathrm{P}, \mathrm{K}$ and $\mathrm{Ca}$, organic osmolytes (Pro and soluble sugars) and phenolic related enzymes such as phenylalanine ammonia lyase (PAL) and POD in sunflower against drought stress.

Similar to other management practices, organic manures have also played a positive role to improve the drought tolerance of sunflower when applied separately or in combination with chemical fertilizers or other OSP (Esmaeilian et al., 2012). Manures are the major source of many essential nutrients as well as enhance the nutrients availability by improving soil physicochemical properties (Hussain et al., 2018). Aowad and Mohamed (2009) and Esmaeilian et al. (2012) reported that when organic manure was applied either alone or in combination with synthetic fertilizers to drought-stressed sunflower, resulting in a significant improvement in drought tolerance.

\section{Flax (Linum usitatissimum L.)}

Water deficit stress conditions (drought) is considered as one of the major harsh abiotic stresses that can inhibit the growth, development, yield and quality of flax. Some drought tolerant genotypes can abide stress by increasing the amount of secondary metabolites. It is reported that accumulation of secondary metabolites such as Pro, GB, sugars and some inorganic ions consider as a defense mechanism of plants to adapt the drought by altering their physiological and biochemical activities (El-Tayeb, 2006; Kiani et al., 2007). In addition, drought stress often leads to accumulating the excessive ROS that causes oxidative stress to the photosynthetic apparatus, which ultimately seriously damage the normal function of cells, finally reduced the total assimilation of plants (Niyogi, 1999; Fambrini et al., 1999). Bakry et al. (2012) found that application 
of SA @ $75 \mathrm{mg}^{-1}$ significantly increased the Pro and free amino acids content of two varieties of flax ('Olin' and 'Amon') under drought condition as compared to the corresponding control condition. Under drought stress, the significant increase in total carbohydrates in shoots of flax concurrently increased the growth rate of the flax that led to increase the photosynthetic efficiency in response to SA treatments and thus led to enhance biosynthesis of carbohydrates which are utilized in growth of flax plants under drought stress (El-Tayeb and Ahmed, 2010). Similarly, Kranner et al. (2002) demonstrated that SA is one of the antioxidant substances that concentrated in the chloroplast of the plant cell and protect the photosynthetic apparatus under drought stress, by reducing the excessively ROS species known as free radicals.

Accumulation Pro and free amino acids in plant tissues could be involved in the osmotic adjustment of plants under drought stress (Delavari et al., 2010) and could also be a protective agent of enzymes and cell membranes (El Tayeb and Ahmed, 2010). Harinasut et al. (2000) reported that when the plant is exposed to drought stress, they are maintaining their water content by the accumulation of compatible OSP, such as Pro, in their cytoplasm. Accumulation of Pro under drought stress produces hydroxyl radical scavenger for increasing stress tolerance in plant species under stress conditions (Hoque et al., 2007). Similarly, Arfan et al. (2007) found that SA is naturally produced in plants in very low amounts that acts as a potential non-enzymatic antioxidant as well as an endogenous plant growth regulator of phenolic nature. Exogenous application of SA helps in the activation of a range of plant defense genes for drought tolerance in plants (Sreenivasulu et al., 2007). Munns and Tester (2008) found that SA has a direct physiological effect through the alteration of antioxidant enzymatic activities by preventing oxidative damage in plants by detoxifying superoxide radicals, produced as a result of stress. The alleviation of oxidative damage and improve the tolerance to environmental stresses, at critical growth stages of the plant, are often correlated with an effectual antioxidative system, such systems may be induced or improved by SA application (He et al., 2005). This significant effect of SA could be attributed to improve in $\mathrm{CO}_{2}$ assimilation and photosynthetic rate which improved mineral uptake by the plant (Noreen and Ashraf, 2008).

\section{Safflower (Carthamus tinctorius L.)}

Plants adopt various strategic tactics to cope with water deficit conditions such as escape, avoidance and tolerance (Rasool et al., 2013). Among the above-mentioned cytosolutes, proline and glycine betaine constitute the most important organic solutes that have a multifunctional role in plants' defense for combating stresses (Hussain et al., 2015). Safflower has proved to be stress tolerant due to having more proline and GB application (Javadipour et al., 2013). Mona et al. (2012) is also in agreement with foliar application of SA during flowering in safflower that increased the production of oleic acid and linoleic acid.

The application of kinetin at $10-5 \mathrm{M}$ as a foliar spray to safflower during flowering (140 days after sowing) was highly effective in increasing oil refractive index (Ullah and Bano, 2011), decreased oil acid value, free fatty acid content (\% oleic acid) and specific gravity but increased oil $\mathrm{pH}$. Kinetin was highly effective in increasing oleic acid (C18:1) but decreased the content of linoleic acid (C18:2) (Ullah and Bano, 2011). Foliar application in stem elongation stage obtained 6.02 percent more seed yield but in the flowering stage, fulvic acid spraying was achieved 35.5\% more oil percent (Moradi et al., 2017). Boydak et al. (2002) reported that treating safflower plants by $\mathrm{GA}_{3}$ had 
less oil content than the non-GA $\mathrm{GA}_{3}$ treated plants. Spraying of Melagrow four times, at 60 or $40 \mathrm{ppm}$ on safflower remarkably increased the oil yields, and percentages carthamin, carthamidin, oleic acid, and oleic/linoleic ratio (Hamza, 2015). Foliar application of zinc and manganese significantly improved the palmitic and oleic acids but these foliar applications reduced linoleic acid content. The palmitic acid content was increased and oleic acid content was decreased by drought stress (Dehnavi and Sanavy, 2008), while the foliar spray of potassium improved the oleic acid content of oil (Pandy et al., 2014).

\section{Peanut (Arachis hypogaea L.)}

Foliar application of LAA has a significant role in improving yield components, biochemical constituents and fatty acids composition in seeds of some groundnut cultivars (NC, Giza 6 and Gregory) grown in sandy soil (Mekki and Hussein, 2017). The addition of soaked poultry glaucoma as organic fertilizer gave the highest yield of peanut under drought stress, but the organic soaked pigeons' manure resulted in high percentage of oil (Abd El-Halim et al., 2016). The recommended dose of fertilizers (RDF) of $\mathrm{P}$ and $\mathrm{K}(100 \%)$ along with $50 \%$ of $\mathrm{N}$ basal and $50 \%$ of $\mathrm{N}$ as top dressing increased the yield attributes, yield and oil contents of groundnut as compared $100 \%$ RDF of N, P, and K to groundnut (Priya et al., 2009). Potassium was reported to play the main role on the oil content of groundnut (Charkaravarthy et al., 2002), and they also reported that potassium application during pod development stage increased the oil content in groundnut.

Phosphorus application in the form of single superphosphate has been shown to increase both oil and protein content of groundnut seed (Elsheikh and Mohamedzein, 1998). Rahman (2006) reported that oil and protein content of groundnut increased when calcium level was increased from $0-100 \mathrm{~kg} \mathrm{ha}^{-1}$. Recently, Vijayarengan et al. (2009) showed that cobalt at the rate of $50 \mathrm{mg} \mathrm{kg}^{-1}$ application in the soil had a beneficial effect on biochemical contents i.e., sugar, protein and amino acids of groundnut seeds compared with control plants. Applying $\mathrm{P}$ fertilizer obviously increased fat and protein content, applying $\mathrm{N}$ fertilizer mainly enhanced protein content, and applying $\mathrm{K}$ fertilizer mainly raised the content of soluble sugar. In addition, the application of NPK fertilizers also increased the contents of lysine and methionine which were inadequate in the protein fractions of peanut kernel, enhanced the contents of oleic acid and linoleic acid, raised the ratio of oleic acid to linoleic acid, improved nutritional quality of peanut, and pronged the shelf life of peanut products (Zhou et al., 2007).

\section{Conclusion}

Drought is the foremost abiotic stress that significantly influenced the qualitative and quantitative traits of major oilseed crops particularly in arid and semi-arid regions. Essential dietary components in human consumption, as well as animal feed, were significantly reduced as a consequence of drought stress through altering the physicobiochemical as well as enzymatic activities of crop plants. Hence, the negative effect of drought stress has been varied in almost all crops depending on crop species, genotypes, and their growth stages. The present review summarized that early growth stages followed by anthesis to grain filling stage of oilseeds crops are the most sensitive stages against drought. The review highlighted that there are different ways to mitigate the 
adverse effect of drought viz., development of crops cultivar tolerant against drought and to follow improved management approaches including exogenous application of osmoprotectants, essential macro and micronutrients management and using organic amendments (compost, green manures, cow dung and incorporation of crop residues) in soils which lead to increase the yield and grain quality of oilseed crop. The findings of the current review will be helpful to plant researchers to make research programs for resolving the consequences of drought stress for sustainable quality food production in the era of climate change.

Disclaimer. We hereby declare that this review contains no material which has been accepted for the award of any degree or diploma in any university and that, to the best of our knowledge and belief, the review contains no copy of any material previously published or written by another person except where due reference is made in the text.

\section{REFERENCES}

[1] Abd El-Fatah, A. A. E. (2007): Comparative study on some flax cultivars. - Journal of Agricultural Science Mansoura University 71(9): 11-19.

[2] Abd El-Halim, A. K., Awad, A. M., EL-Moursy, M. (2016): Response of Peanut to Some Kinds of Organic Fertilizers under Drip and Sprinkler Irrigation Systems. - Alexandria Science Exchange Journal 374: 703-713.

[3] Abdelaal, A. A. Kh., Hafez, Y. M., EL Sabagh, A. (2017): Ameliorative effects of abscisic acid and yeast on morpho-physiological and yield characters of maize (Zea mays L.) plants under water deficit conditions. - Fresenius Environmental Bulletin 26(12):7372-7383.

[4] Ahanger, M. A., Akram, N. A., Ashraf, M., Alyemeni, M. N., Wijaya, L., Ahmad, P. (2017): Plant responses to environmental stresses - from gene to biotechnology. - AoB Plants. 9(4). doi.org/10.1093/aobpla/plx025.

[5] Ahmadi, S. A. K., Ebadi, A., Daneshian, J., Jahanbakhsh, S., Siadat, S. A., Tavakoli, H. (2015): Effects of irrigation deficit and application of some growth regulators on defense mechanisms of canola. - Notulae Botanicae Horti Agrobotanici Cluj-Napoca 43(1): 12430 .

[6] Akande, S. R., Taiwo, L. B., Adegbite, A. A., Owolade, O. F. (2009): Genotype x environment interaction for soybean grain yield and other reproductive characters in the forest and savanna agro-ecologies of South-west Nigeria. - African Journal of Plant Science 3(6): 127-132.

[7] Ali, Q. (2011): Exogenous use of some potential organic osmolytes in enhancing drought tolerance in maize (Zae mays L.). - A thesis submitted in partial fulfillment of the requirements for the degree of doctor of philosophy. Botany Dep., Fac. of Sci., Univ. of Agric., Faisalabad, Pakistan, pp.312.

[8] Ali, Q., Ashraf, M. (2011): Exogenously applied glycinebetaine enhances seed and seed oil quality of maize (Zea mays L.) under water deficit conditions. - Environmental and Experimental Botany 71: 249-259.

[9] Ali, Q., Anwar, F., Ashraf, M., Saari, N., Perveen, R. (2013): Ameliorating effects of exogenously applied proline on seed composition, seed oil quality and oil antioxidant activity of maize (Zea mays L.) under drought stress. - International Journal of Molecular Science 14: 818-835.

[10] Ali, M., Khan, G., Akbar, F. (2014): The effect of different levels of irrigation and potassium $(\mathrm{K})$ application on seed erucic content for different varieties of brassica under field conditions. - Chemistry and Materials Research 6: 97-100. 
[11] Ali, S., Liu, Y., Ishaq, M., Shah, T., Ilyas, A., Din, I. U. (2017): Climate Change and Its Impact on the Yield of Major Food Crops: Evidence from Pakistan. - Foods 6(6): 39. doi.org/10.3390/foods6060039.

[12] Alqudah, A. M., Samarah, N. H., Mullen, R. E. (2010): Drought stress effect on crop pollination, seed set, yield and quality. - In: Lichtfouse, E. (ed.) Alternative Farming Systems, Biotechnology, Drought Stress and Ecological Fertilization. Berlin: Springer, 193-213.

[13] Al-Tawaha, A. M, Seguin, P., Smith, D. L, Bonnell, R. B. (2007): Irrigation level affects isoflavone concentrations of early maturing soya bean cultivars. - Journal of Agronomy and Crop Science 193: 238-246.

[14] Amini, H., Arzani, A., Karami, M. (2014): Effect of water deficiency on seed quality and physiological traits of different safflower genotypes. - Turkish Journal of Biology 38(2): 271-282.

[15] Amir, Y., Benbelkacem, T., Hadni, L., Youyou, A. (2005): Effect ofirrigation and fertilization on the characteristic of peanutseeds cultivated near tızı- ouzou. - Electronic Journal of Environmental, Agricultural and Food Chemistry 4:879885.

[16] Anastasi, U., Santonoceto, C., Giuffrè, A. M., Sortino, O., Gresta, F., Abbate, V. (2010): Yield performance and grain lipid composition of standard and oleic sunflower as affected by water supply. - Field Crops Research 119: 145-153.

[17] Aowad, M. M., Mohamed, A. A. (2009): The effect of bio, organic and mineral fertilization on productivity of sunflower seed and oil yields. - Journal of Agricultural Research 35: 1013-28.

[18] Arfan, M., Athar, H. R., Ashraf, M. (2007): Does exogenous application of salicylic acid through the rooting medium modulate growth and photosynthetic capacity in two differently adapted spring wheat cultivars under salt stress? - Journal of Plant Physiology 164 (6): 685-94.

[19] Arshad, M., Naazar, A., Ghafoor, A. (2006): Character correlation and path coefficient in soybean Glycine max (L) Merrill. - Pakistan Journal of Botany 38: 121-130.

[20] Arslan, B., Kucuk, M. (2005): Oil content and fatty acid composition of some safflower cultivars in Van (Turkey). - In: 6th international safflower conference, Istanbul, 6-10 June, pp 67-175.

[21] Ashraf, M., Abid, M., Teixeira da Silva, J. A., Shahzad, S. M., Hussain, A., Imtiaz, M. (2015): Silicon and potassium nutrition enhances salt adaptation capability of sunflower by improving plant water status and membrane stability. - Communications in Soil Science and Plant Analysis 46(8): 991-1005.

[22] Ashrafi, E., Razmjoo, K. (2010): Effect of irrigation regimes on oil content and composition of safflower (Carthamus tinctorius L.) cultivars. - Journal of the American Oil Chemists' Society 87(5): 499-506. doi:10.1007/s11746-009-1527-8.

[23] Aslam, M. N., Nelson, M. N., Kailis, S. G., Bayliss, K. L., Speijers, J., Cowling, W. A. (2009): Canola oil increases in polyunsaturated fatty acids and decreases in oleic acid in drought-stressed Mediterranean-type environments. - Plant Breeding 128(4): 348-355.

[24] Babaeian, M., Tavassoli, A., Ghanbari, A., Esmaeilian, Y., Fahimifard, M. (2011): Effects of foliar micronutrient application on osmotic adjustments, grain yield and yield components in sunflower (Alstar cultivar) under water stress at three stages. - African Journal of Agricultural Research 6(5): 1204-8.

[25] Bagheri, H., Sam-Daliri, M. (2011): Effect of water stress on agronomic traits of spring safflower cultivars (Carthamus tinctorius L.). - Australian Journal of Basic and Applied Science 5: 2621-2624.

[26] Bagheri, H., Andalibi, B., Moghaddam, M., Zangani, S., Soleiman, S. (2012): Safflower (Carthamus tinctorius cv. Sina) oil and seed yield improvement in rain fed Condition by atrazine foliar application. - Annals of Biological Research 3: 1202-1209. 
[27] Baldini, M., Givanardi, R., Vanozzi, G. P. (2000): Effect of different water availability on fatty acid composition of the oil in standard and high oleic sunflower hybrids. - In: Proceedings of XV international sunflower conference, Toulouse, pp A79.84.

[28] Baldini, M., Giovanardi, R., Tahmasebi-enferadi, S., Vannozzi, G. (2002): Effects of water regime on fatty acid accumulation and final fatty acid composition in the oil of standard and high oleic sunflower hybrids. - Italian Journal of Agronomy 6: 119-126.

[29] Barutçular, C., Yıldırım, M., Koç, M., Akıncı, C., Tanrıkulu, A., EL Sabagh, A., Saneoka, H., Ueda, A., Islam, M. S., Toptas, I., Albayrak, O., Tanrikulu, A. (2016): Quality traits performance of bread wheat genotypes under drought and heat stress conditions. Fresenius Environmental Bulletin ,25(12a): 6159-6165.

[30] Bauer, P. J., Stone, K. C., Foulk, J. A., Dodd, R. B. (2015): Irrigation and cultivar effect on flax fiber and seed yield in the Southeast USA. - Industrial Crops and Products 67: 710.

[31] Bellaloui, N., Mengistu, A., Kassem, M. A. (2013): Effects of genetics and environment on fatty acid stability in soybean seed. - Food Nutrition Science 4: 165-175.

[32] Bielach, A., Hrtyan, M., Tognetti, V. B. (2017): Plants under stress: Involvement of auxin and cytokinin. - International Journal of Molecular Sciences 18(7): 1427.

[33] Blum, A. (2016): Osmotic adjustment is a prime drought stress adaptive engine in support of plant production. - Plant, Cell and Environment doi: 10.1111/pce.12800.

[34] Bouchereau, A., Bensaoud, A., Clossais-Besnard, N., Renard, M. (1996): Water stress effects on rapeseed quality. - European Journal of Agronomy 5(2): 19-30.

[35] Bowsher, K., Civillico, E. F., Coburn, J., Collinger, J., Contreras-Vidal, J. L., Denison, T., Donoghue, J., French, J., Getzoff, N., Hochberg, L. R., Hoffmann, M. (2016): Braincomputer interface devices for patients with paralysis and amputation: a meeting report. Journal of Neural Engineering 13(2): 023001.

[36] Boydak, E., Alpaslan, M., Hayta, M., Gercek, S., Simek, M. (2002): Seed composition of soybeans grown in the Harran region of Turkey as affected by row spacing and irrigation. - Journal Agricultural and Food Chemistry 50: 4718-4720.

[37] Boydak, E., Karaaslan, D., Turkoglu, H. (2010): The effect of different nitrogen and irrigation levels on fatty acid composition of peanut oils. - Turkish Journal of Field Crops 15: 29-33.

[38] Britz, S. J., Kremer, D. F. (2002): Warm temperatures or drought during seed maturation increase free alphatocopherol in seeds of soybean (Glycine max L, Merr.). - Journal Agricultural and Food Chemistry 50: 6058-6063.

[39] Brumm, T. J., Hurburgh, C. R., Johnson, L. A. (1990): Cracking and Dehulling Shriveled and Wrinkled Soybeans. - Journal of the American Oil Chemists' Society 67: 750-756.

[40] Carrera, C., Martinez, M. J., Dardanelli, J., Balzarini, M. (2009): Water deficit effect on the relationship between temperatures during the seed fill period and soybean seed oil and protein concentrations. - Crop Science 49: 990-998.

[41] Connor, D. J., Loomis, R. S., Cassman, K. G. (2011): Crop ecology: productivity and management in agricultural systems. - Cambridge University Press.

[42] Conroy, J. P., Küppers, M., Küppers, B., Virgona, J., Barlow, E. W. (1988): The influence of $\mathrm{CO} 2$ enrichment, phosphorus deficiency and water stress on the growth, conductance and water use of Pinus radiata D. Don. - Plant, Cell \& Environment 11(2): 91-8. https://doi.org/10.1111/1365-3040.ep11604890.

[43] Cooper, P. J. M., Gregory, P. J., Keating, J. D. H., Brown, S. C. (1987): Effect of fertilizer, variety and location on barley production under rainfed conditions in northern Syria. 2. Soil water dynamics and crop water use. - Field crops Research 16: 67-84.

[44] Dawood, M. G., Sadak, M. S. (2014): Physiological role of glycinebetaine in alleviating the deleterious effects of drought stress on canola plants (Brassica napus L.). - Middle East Journal of Agriculture Research 3(3): 638-644.

[45] Debaeke, P., Bedoussac, L., Bonnet, C., Bret-Mestries, E., Seassau, C., Gavaland, A., Raffaillac, D., Tribouillois, H., Véricel, G., Justes, E. (2017): Sunflower crop: 
environmental-friendly and agroecological. $\quad-\quad$ OCL 24(3): D304. doi.org/10.1051/ocl/2016052.

[46] Dehnavi, M. M., Sanavy, S. A. M. M. (2008): Effects of withholding irrigation and Foliar Application of Zinc and Manganese on Fatty Acid Composition and Seed Oil Content in Winter Safflower. - 7th International Safflower Conference, Wagga Wagga, New South Wales, Australia, 1-6.

[47] Dolatabadian, A., Jouneghani, R. S. (2009): Impact of exogenous ascorbic acid on antioxidant activity and some physiological traits of common bean subjected to salinity stress. - Notulae Botanicae Horti Agrobotanici Cluj-Napoca 37(2): 165-72.

[48] Dornbos, D. L., Mullen, R. E. (1992): Soybean seed protein and oil contents and fatty acid composition adjustments by drought and temperature. - Journal of American Oil and Chemical Society 69: 228-231.

[49] Dwivedi, S. L., Nigam, S. N., Rao, N. R. C., Singh, U., Rao, K. V. S. (1996): Effect of drought on oil, fatty acids and protein contents of groundnut (Arachis hypogaea L.) seeds. - Field Crop Research 48: 125-133.

[50] Dwivedi, S. L., Upadhyaya, H. D., Hegde, D. M. (2005): Development of core collection using geographic information and morphological descriptors in safflower (Carthamus tinctorius L.) germplasm. - Genetic Resources and Crop Evolution 52(7): 821-30.

[51] El-Bana, I. M. (2000): Soil Management of sunflower crop under the interaction of mineral and Biofertilizer. - Ph. D. Thesis, Faculty of Agric. Mansoura Univ., Egypt.

[52] El-Beltagi, H. S., Salama, Z. A., El-Hariri, D. M. (2007): Evaluation of fatty acids profile and the content of some secondary metabolites in seeds of different flax cultivars (Linum usitatissimum L.). - General and Applied Plant Physiology 33(3-4): 187-202.

[53] El-Lethy, S. R., Hasnaa, S. A. Y., Talaat, I. M. (2010): Physiological effect of some antioxidant on flax plant (Linum usitatissimum L.). - World Journal of Agricultural Science 6(5): 622-629.

[54] El-Mohsen, A. A. A., Mahmoud, G. O., Safina, S. A. (2013): Agronomical evaluation of six soybean cultivars using correlation and regression analysis under different irrigation regime conditions. - Journal of Plant Breeding and Crop Science 5(5): 91-102.

[55] El-Refaey, R. A., El-Seidy, E. H., Abou-Zaied, T. A., Rashwan, E. A. (2010): Evaluation of some genotypes of flax (Linum usitatissimum L.) for fiber and its related characters under different plant densities and retting methods. - The $12^{\text {th }}$ Conference of Agronomy, Suez Canal Univ., Fac., Environ., Agric. Sci., El- Arish, Egypt. 20-22 September 2010, pp. 165-187.

[56] EL Sabagh, A., Hossain, A., Barutçular, C., Islam MS., Ratnasekera, D., Kumar, N., Meena, R.S., Gharib, H.S., Saneoka, H., Teixeira da Silva, J.A. (2019a): Drought and salinity stress management for higher and sustainable canola (Brassica napus L.) production: a critical review. - Australian Journal of Crop Science 13(01):88-97.

[57] EL Sabagh, A., Hossain, A., Islam, MS., Barutçular, C., Ratnasekera, D., Kumar, N., Meena, R.S. Gharib, H.S., Saneoka, H., Teixeira da Silva, J.A. (2019b): Salinity stress management for sustainable soybean production using foliar application of compatible antioxidants and soil application of organic fertilizers: a critical review. - Australian Journal of Crop Science 13(02): 228-236.

[58] EL Sabagh., A., Sorour, S., Omar, A. E., Islam, M. S., Ueda, A., Saneoka, H., Barutçular, C. (2015): Soybean (Glycine Max L.) growth enhancement under Water Stress Conditions. - International Conference on Chemical, Agricultural and Biological Sciences (CABS-2015) Sept. 4-5, 2015, Istanbul (Turkey). doi.org/10.17758/ERPUB.ER915116.

[59] EL Sabagh, A., Sorour, S., Morsi, A., Islam, M. S., Ueda, A., Barutçular, C., Arioglu, H., Saneoka, H. (2016): Role of OSP and compost application in improving water stress tolerance in soybean (Glycine max L.). - International Journal of Current Research 8(2): 25949-25954. 
[60] EL Sabagh, A., Abdelaal, Kh A.A., Barutçular, C. (2017): Impact of plant originated antioxidants supplementation on growth, yield and quality traits of canola plants (Brassica napus L.) in north nile delta under different irrigation conditions. - Journal of Experimental Biology and Agricultural Sciences 5(2): 163-172.

[61] El-Sadek, A. N. (2005): Effect of some agronomic practices on sunflower productivity in new valley. - M.Sc. Thesis, Faculty of Agric. Ain Shams Univ., Egypt.

[62] El-Tayeb, M. A. (2005): Response of Barley Grains to the Interactive Effect of Salinity and Salicylic Acid. - Plant Growth Regulator 45: 215-224.

[63] El-Tayeb, M. A., El-Enany, A. E., Ahmed, N. L. (2006): Salicylic acid-induced adaptive response to copper stress in sunflower (Helianthus annuus L.). - Plant Growth Regulation 50(2-3): 191-9.

[64] El-Tayeb, M. A., Ahmed, N. L. (2010): Response of wheat cultivars to drought and salicylic acid. - American-Eurasian Journal of Agronomy 3(1): 1-7.

[65] Elsheikh, E. A. E., Mohamedzein, E. M. M. (1998): Effect of Bradyrhizobium, VA mycorrhiza and fertilizers on seed composition of groundnut. - Annals of Applied Biology 132: 325-330.

[66] Ensiye, A., Khorshid, R. (2010): Effect of irrigation regimes on oil content and composition of safflower (Carthamus tinctorius L.) cultivars. - Journal of American Oil and Chemical Society: 1527-8.

[67] Esmaeilian, Y., Sirousmehr, A., Asgripour, M., Amiri, E. (2012): Comparison of sole and combined nutrient application on yield and biochemical composition of sunflower under water stress. - International Journal of Applied Science and Technology 2(3): 214-220.

[68] Fahad, S., Bajwa, A. A., Nazir, U., Anjum, S. A., Farooq, A., Zohaib, A., Sadia, S., Nasim, W., Adkins, S., Saud, S., Ihsan, M. Z., Alharby, H., Wu, C., Wang, D., Huang, J. (2017): Crop Production under Drought and Heat Stress: Plant Responses and Management Options. - Frontier in Plant Science 8: 1147. doi: 10.3389/fpls.2017.01147.

[69] Fambrini, M., Guidi, L., Castagna, A., Vernieri, P., Ferraro, F., Durante, M., Pugliesi, C. (1999): The sunflower (Helianthus annuus L.) mutant xan-1 is impaired in photosynthetic activity. - In XLIII convegno annuale Società di Genetica Agraria: 134-134.

[70] Farooq, M. U., Habib, M. A., Rehman, A., Wahid, A., Munir, R. (2011): Employing aqueous allelopathic extracts of sunflower in improving salinity tolerance of rice. Journal of Agriculture and Social Science 7: 75-80.

[71] Fernández-Cuesta, Á., Velasco, L., Ruiz-Méndez, M. V. (2014): Novel safflower oil with high $\gamma$-tocopherol content has a high oxidative stability. - European Journal of Lipid Science and Technology 116(7): 832-836. doi:10.1002/ejlt. 201300208.

[72] Filová, A., Sytar, O., Krivosudská, E. (2013): Effects of brassinosteroid on the induction of physiological changes in Helianthus annuus L. under copper stress. - Acta Universitatis Agriculturae et Silviculturae Mendelianae Brunensis 61(3): 623-9.

[73] Filová, A. (2014): The Responses of Helianthus annuus L. to foliar apllication of 28homobrassinolide. - Research Journal of Agricultural Science 46(1): 226-239.

[74] Foroud, N., Mundel, H., Saindon, G., Entz, T. (1993): Effect of level and timing of moisture stress on soybean yield, protein and oil responses. - Field Crops Research 31: 195-209.

[75] Franklin, P., Gardner, R., Pearce, B., Mitchell, R. L. (2010): Physiology of crop plants. Scientific Press, 336 pp.

[76] Fulda, S., Mikkat, S., Stegmann, H., Horn, R. (2011): Physiology and proteomics of drought stress acclimation in sunflower (Helianthus annuus L.). - Plant Biology 13(4): 632-42.

[77] Gandah, M., Bouma, J., Brown, J., Hiernaux, P., Van-Duivenbooden, N. (2003): Strategies to optimize allocation of limited nutrients to sandy soils of the Sahel: a case study from Niger, West Africa. - Agriculture, Ecosystem and Environment 94: 311-319. 
[78] Gao, J., Hao, X., Thelen, K. D., Robertson, G. P. (2009): Agronomic management system and precipitation effects on soybean oil and fatty acid profiles. - Crop Science 49: 10491057.

[79] Gecgel, U., Demirci, M., Esendal, E., Tasan, M. (2007): Fatty acid composition of the oil from developing seeds of different varieties of safflower (Carthamus tinctorius L.). Journal of the American Oil Chemists' Society 84(1): 47-54.

[80] Ghanbari, A. A., Mousavi, S. H., Mousapour Gorgi, A., Rao, I. M. (2013): Effects of water stress on leaves and seeds of bean (Phaseolus vulgaris L.). - Turkish Journal of Field Crops 18: 73-77.

[81] Gulluoglu, L., Bakal, H., Onat, B., EL Sabagh, A., Arioglu, H. (2016): Characterization of peanut (Arachis hypogaea L.) seed oil and fatty acids composition under different growing season under mediterranean environment. - Journal of Experimental Biology and Agricultural Sciences 5 (Suppl.): 565-571.

[82] Hamza, M. (2015): Improving petal, seed and oil yields of safflower using melagrow, gibberellic acid and cytokinin. - Journal of Plant Production, Mansoura University 6(6): 809-820.

[83] Harinasut, P., Srisunak, S., Pitukchaisopol, S., Charoensataporn, R. (2000): Mechanisms of adaptation to increasing salinity of mulberry: Proline content and ascorbate peroxidase activity in leaves of multiple shoots. - Science Asia 26(26): 207-11.

[84] Hasanah, Y., Mawarni, L., Irmansyah, T. (2017): The Foliar Application of Exogenous Antioxidant for increasing drought tolerance in soybean. - International Journal of ChemTech Research 10(2): 156-162.

[85] Hasanah, Y., Nisa, T. C., Armidin, H., Hanum, H. (2017): Isoflavone content of soybean (Glycine $\max (\mathrm{L})$. Merr.) cultivars with different nitrogen souces and growing season under dry land conditions. - http://repository.usu.ac.id/handle/123456789/69058.

[86] Hashim, I. B., Koehler, P. E., Eitenmiller, R. R., Kvien, C. K. (1993): Fatty acid composition and tocopherol content of drought stressed Florunner peanuts. - Peanut Science 20: 21-24.

[87] Jahan, M.A.H.S., Hossain, A., Teixeira da Silva, J.A., EL Sabagh, A., Rashid, M.H., Barutçular, C. (2019): Effect of Naphthaleneacetic Acid on Root and Plant Growth and Yield of Ten Irrigated Wheat Genotypes. - Pakistan Journal of Botany 51(2), DOI: 10.30848/PJB2019-2(11).

[88] Hemmati, M. H., Soleymani, A. (2014): A study about some physiological indices of sunflower growth under drought stress. - International Journal of Advanced Biological and Biomedical Research 2(3): 553-63.

[89] Henry, J. L., MacDonald, K. B. (1978): The effects of soil and fertilizer nitrogen and moisture stress on yield, oil and protein concentration of rape. - Canadian Journal of Soil Science 58: 303-310.

[90] Hoque, M. A., Okuma, E., Banu, M. N., Nakamura, Y., Shimoishi, Y., Murata, Y. (2007): Exogenous proline mitigates the detrimental effects of salt stress more than exogenous betaine by increasing antioxidant enzyme activities. - Journal of Plant Physiology 164(5): 553-61.

[91] Hossain, A., Sarker, M. A. Z., Saifuzzaman, M., Teixeira da Silva, J. A., Lozovskaya, M. V., Akhter, M. M. (2013): Evaluation of growth, yield, relative performance and heat susceptibility of eight wheat (Triticum aestivum L.) genotypes grown under heat stress. International Journal of Plant Production 7: 615-636.

[92] Huberman, M., Roiv, J., Goldschmidt, E. E., Apelbaum, A., Goren, R. (2014): The novel ethylene antagonist, 3-cyclopropyl-1-enyl-propanoic acid sodium salt (CPAS), increases grain yield in wheat by delaying leaf senescence. - Plant Growth Regulation 73: 249-255.

[93] Hussain, M., Malik, M. A., Farooq, M., Ashraf, M. Y., Cheema, M. A. (2008): Improving drought tolerance by exogenous application of glycinebetaine and salicylic acid in sunflower. - Journal of Agronomy and Crop Science 194: 1439. 
[94] Hussain, M. I., Lyra, D. A., Farooq, M., Nikolaos, N., Khalid, N. (2015): Salt and drought stresses in safflower: a review. - Agronomy for Sustainable Development 36:4.

[95] Hussain, M., Farooq, S., Hasan, W., Ul-Allah, S., Tanveer, M., Farooq, M., Nawaz, A. (2018): Drought stress in sunflower: Physiological effects and its management through breeding and agronomic alternatives. - Agricultural Water Management 201: 152-66.

[96] Hussain, S., Saleem, M. F., Iqbal, J., Ibrahim, M., Atta, S., Ahmed, T., Rehmani, M. I. (2014): Exogenous application of abscisic acid may improve the growth and yield of sunflower hybrids under drought. - Pakistan Journal of Agricultural Sciences 51(1): 4958.

[97] Hussain, S., Saleem, M. F., Iqbal, J., Ibrahim, M., Ahmad, M., Nadeem, S. M., Ali, A., Atta, S. (2015): Abscisic acid mediated biochemical changes in sunflower (Helianthus annuus L.) grown under drought and well-watered field conditions. - The Journal of Animal and Plant Sciences 25: 406-16.

[98] Intergovernmental Panel on Climate Change (IPCC) (2012): Managing the Risks of Extreme Events, and Disasters to Advance Climate Change Adaptation. - Cambridge: Cambridge University Press.

[99] Iqbal, N., Nazar, R., Khan, N. A. (eds.) (2015): Osmolytes and plants acclimation to changing environment: emerging omics technologies. - Springer, Nature. doi.org/10.1007/978-81-322-2616-1.

[100] Islam, M. S., Akhter, M. M., EL Sabagh, A., Liu, L. Y., Nguyen, N. T., Ueda, A., Saneoka, H. (2011): Comparative studies on growth and physiological responses to saline and alkaline stresses of Foxtail millet (Setaria italica L.) and Proso millet (Panicum miliaceum L.). - Australian Journal of Crop Science 5(10): 1269-1277.

[101] Jaleel, C. A., Manivannan, P. A., Wahid, A., Farooq, M., Al-Juburi, H. J., Somasundaram, R. A., Panneerselvam, R. (2009): Drought stress in plants: a review on morphological characteristics and pigments composition. - International Journal of Agriculture and Biology 11(1): 100-5.

[102] Jasso de Rodriguez, D., Phillips, B. S., Rodriguez-Garcia, R., Angulo-Sanchez, J. L. (2002): Grain yield and fatty acid composition of sunflower seed for cultivars developed under dry land conditions. - In: Janick, J., Whipkey, A. (eds.) Trends in new crops and new uses. ASHS Press, Alexandria, VA. p. 139-142.

[103] Javadipour, Z., Movahhedi Dehnavi, M., Balouchi, H. (2013): Changes in leaf proline, soluble sugars, glycinebetaine and protein content in six spring safflower under salinity stress. - Journal of Plant Process Function 1(2): 13-23.

[104] Kiani, S. P., Grieu, P., Maury, P., Hewezi, T., Gentzbittel, L., Sarrafi, A. (2007): Genetic variability for physiological traits under drought conditions and differential expression of water stress-associated genes in sunflower (Helianthus annuus L.). - Theoretical and Applied Genetics 114(2): 193-207.

[105] Kottapalli, K. R., Rakwal, R., Shibato, J., Burow, G., Tissue, D., Burke, J., Puppala, N., Burow, M., Payton, P. (2009): Physiology and proteomics of the water-deficit stress response in three contrasting peanut genotypes. - Plant, Cell \& Environment 32(4): 380407. https://doi.org/10.1111/j.1365-3040.2009.01933.x.

[106] Lacombe, S., Souyris, I., Bervillé, A. J. (2009): An insertion of oleate desaturase homologous sequence silences via siRNA the functional gene leading to high oleic acid content in sunflower seed oil. - Molecular Genetics and Genomics 281(1): 43-54.

[107] Maclagan, J. L. (1993): Effect of drought stress on the water relation in Brassica species. - Canadian Journal of Plant Physiological Science 73: 225-229.

[108] Maleki, A., Naderi, A., Naseri, R., Fathi, A., Bahamin, S., Maleki, R. (2013): Physiological Performance of Soybean Cultivars under Drought Stress. - Bulletin of Environment, Pharmacology and Life Sciences 2(6): 38-44.

[109] Mekki, B. E. D. B., Hussein, H. A. A. (2017): Influence of L-ascorbate on yield components, biochemical constituents and fatty acids composition in seeds of some 
groundnut (Arachis hypogaea L.) cultivars grown in sandy soil. - Bioscience Research 14(1): 75-83.

[110] Mendelsohn, R. (2014): The impact of climate change on agriculture in Asia. - Journal of Integrated Agriculture 13: 660-665. doi: 10.1016/S2095-3119(13)60701-7.

[111] Mirshekari, M., Amiri, R., Nezhad, H., Noori, S. A. S., Zandvakili, O. R. (2012): Effects of planting date and water deficit on quantitative and qualitative traits of flax seed. American-Eurasian Journal of Agriculture and Environmental Science 12(7): 901-913.

[112] Moghadam, H. R. T., Zahedi, H., Ghooshchi, F. (2011): Oil quality of canola cultivars in response to water stress and super absorbent polymer application. - Pesquisa Agropecuária Tropical 41(4): 579-586.

[113] Mohammadi, M., Ghassemi-Golezani, K., Zehtab-Salmasi, S., Nasrollahzade, S. (2016): Assessment of Some Physiological Traits in Spring Safflower (Carthamus tinctorius L.) Cultivars under Water Stress. - International Journal of Life Sciences 10(1): 58-64.

[114] Mohammadi, M., Ghassemi-Golezani, K., Chaichi, M. R., Safikhani, S. (2018): Seed Oil Accumulation and Yield of Safflower Affected by Water Supply and Harvest Time. Agronomy Journal 110: 1-8.

[115] Mohammadkhani, N., Heidari, R. (2008): Effects of Drought Stress on Soluble Proteins in two Maize Varieties. - Turkish Journal of Biology 32: 23-30.

[116] Mona, G., Dawood, M., Sadak, S., Hozayen, M. (2012): Physiological role of salicylicacid in improving performance, yield and some biochemical aspects of sunflower plant grown under newly reclaimed sandy soil. - Australian Journal of Basic \& Applied Science 4: 82-89.

[117] Moradi, P., Pasari, B., Fayyaz, F. (2017): The effects of fulvic acid application on seed and oil yield of safflower cultivars. - Journal of Central European Agriculture 18(3): 584597.

[118] Movahhedy-Dehnavy, M., Modarres-Sanavy, S. A., Mokhtassi-Bidgoli, A. (2009): Foliar application of zinc and manganese improves seed yield and quality of safflower (Carthamus tinctorius L.) grown under water deficit stress. - Industrial Crops and Products 30(1): 82-92.

[119] Munns, R., Tester, M. (2008): Mechanisms of salinity tolerance. - Annual Review of Plant Biology 59: 651-81.

[120] Nabipour, M., Meskarabashee, M., Yousefpour, H. (2007): The effect of water deficit on yield and yield components of safflower (Carthamus tinctorius L.). - Pakistan Journal of Biological Science 10(3): 421-426.

[121] Narusaka, Y., Nakashima, K., Shinwari, Z. K., Sakuma, Y., Furihata, T., Abe, H., Narusaka, M., Shinozaki, K., Yamaguchi-Shinozaki, K. (2003): Interaction between two cis-acting elements, ABRE and DRE, in ABA-dependent expression of Arabidopsis rd29A gene in response to dehydration and high-salinity stresses. - The Plant Journal 34(2): 137-48.

[122] Nazari, M., Mirlohi, A., Majidi, M. M. (2017): Effects of Drought Stress on Oil Characteristics of Carthamus Species. - Journal of American Oil and Chemistry Society 94: 247-256.

[123] Niyogi, K. K. (1999): Photoprotection revisited: genetic and molecular approaches. Annual Review of Plant Biology 50(1): 333-59.

[124] Noreen, S. I., Ashraf, M. U. (2008): Alleviation of adverse effects of salt stress on sunflower (Helianthus annuus L.) by exogenous application of salicylic acid: growth and photosynthesis. - Pakistan Journal of Botany 40(4): 1657-63.

[125] Oraki, H., Aghaalikhana, M. (2012): Effect of water deficit stress on proline contents, soluble sugars, chlorophyll and grain yield of sunflower (Helianthus annuus L.) hybrids. - African journal of Biotechnology 11(1): 164-8.

[126] Pandey, A., Kumar, A., Thongbam, P. D. (2014): Rice quality under water stress. International Journal of Ayurveda and Pharmaceutical Research 4: 2347-2358. 
[127] Perez-Adamor, M. A., Leon, J., Green, P. J., Carbonell, J. (2002): Induction of the arginine decarboxilase ADC2 gene provides evidence for the involvement of polyamines in the wound response in Arabidopsis. - Plant Physiology 130: 1454-1463.

[128] Petcu, E., Adrian, A., Danil, S. (2001): The effect of drought stress on fatty acid composition in some Romanian sunflower hybrids. - Romanian Agric Res 15: 39-42.

[129] Pierre, C. S., Peterson, C. J., Ross, A. S., Ohm, J., Verhoeven, M. C., Larson, M., White, B. H. (2008): Wheat grain quality changes with genotype, nitrogen fertilization, and water stress. - Agronomy Journal 100: 414-420.

[130] Pritchard, F. (2007): Challenges for irrigated Canola in 2007. - Information sourced from IREC farmers Newsletter, No. 175.

[131] Priya, S., Inman, D. J. (eds.) (2009): Energy harvesting technologies. - Springer, Boston, MA. https://doi.org/10.1007/978-0-387-76464-1.

[132] Qaderi, M., Kurepin, L. V., Reid, D. M. (2006): Growth and physiological responses of canola (Brassica napus) to three components of global climate change: temperature, carbon dioxide and drought. - Physiologia Plantarum 128: 710-721.

[133] Rabert, G. A., Rajasekar, M., Manivannan, P., Somasundaram, R., Panneerselvam, R. (2013): Effect of triazole fungicide on biochemical and antioxidant enzymes activity in okra (Abelmoschus esculentus L.) plant under drought stress. - International Journal of Agriculture and Food Science 3(3): 100-7.

[134] Rad, A. H. S., Zandi, P. (2012): Comparison of winter and spring rapeseed cultivars considering their oil content and fatty acid composition. - American-Eurasian J. Agric. and Environ. Science 12(6): 775-780.

[135] Rahman, M. A. (2006): Effect of Calcium and Bradyrhizobium inoculation of the Growth, Yield and quality of groundnut (A. hypogaea L.). - Bangladesh Journal of Scientific and Industrial Research 41(3-4): 181-188.

[136] Rashwan, E., Mousa, A., EL Sabagh, A., Barutçular, C. (2016): Yield and quality traits of some flax cultivars as influenced by different irrigation intervals. - Journal of Agricultural Science 8: 226-240. http://dx.doi.org/10.5539/jas.v8n10p226.

[137] Rasool, S., Ahmad, A., Siddiqi, T. O., Ahmad, P. (2013): Changes in growth, lipid peroxidation and some key antioxidant enzymes in chickpea genotypes under salt stress. Acta Physiol Plant 35(4): 1039-1050.

[138] Rauf, S., Sadaqat, H. A. (2007): Effects of varied water regimes on root length, dry matter partitioning and endogenous plant growth regulators in sunflower (Helianthus annuus L.). - Journal of Plant Interactions 2(1): 41-51.

[139] Reddy, T. Y., Reddy, V. R., Anbumozhi, V. (2003): Physiological responses of groundnut (Arachis hypogea L.) to drought stress and its amelioration: a critical review. Plant Growth Regul. 41(1): 75-88.

[140] Rondanini, D., Savin, R., Hall, A. J. (2003): Dynamics of fruit growth and oil quality of sunflower (Helianthus annuus L.) exposed to brief intervals of high temperature during grain filling. - Field Crops Research 83(1): 79-90.

[141] Rotundo, J. L., Westgate, M. E. (2010): Rate and duration of seed component accumulation in water-stressed soybean. - Crop Science 50: 676-684. doi.org/10.2135/cropsci2009.05. 0240.

[142] Samrah, N. H., Mullen, R. E., Anderson, I. (2009): Soluble sugar contents, germination and vigor of soybean seeds in response to drought stress. - Journal of New Seeds 10: 6373.

[143] Sculer, I., Milon, A., Nakatani, Y., Ourisson, G., Albercht, A. M., Benveniste, P. (1991): Differential effects of plant sterols on water permeability and on acyl chain ordering of soybean phosphatidyl choline bilayers. - Preceding of the National Academy of Sciences of USA 88: 6926-6930.

[144] Serraj, R., Sinclair, T. R. (2002): Osmolyte accumulation: Can it really help increase crop yield under drought conditions? - Plant Cell Environment 25: 333-341. 
[145] Shim, Y. Y., Gui, B., Wang, Y., Reaney, M. J. (2015): Flaxseed (Linum usitatissimum L.) oil processing and selected products. - Trends in Food Science \& Technology 43(2): 16277.

[146] Silvente, S., Sobolev, A. P., Lara, M. (2012): Metabolite adjustments in drought tolerant and sensitive soybean genotypes in response to water stress. - PLoS One 7(6):p.e38554.

[147] Singh, S., Sinha, S. (2005): Accumulation of metals and its effects in Brassica juncea L. Czern. (cv. Rohini) grown on various amendments of tannery waste. - Ecotoxicology and Environmental Safety 62: 118-127.

[148] Smiciklas, K. D., Mullen, R. E., Carlson, R. E., Knapp, A. D. (1992): Soybean seed quality response drought stress and pod position. - Agronomy Journal 84: 166-170.

[149] Soleimanzadeh, H., Habibi, D., Ardakani, M. R., Paknejad, F., Rejali, F. (2010): Effect of potassium levels on antioxidant enzymes and malondialdehyde content under drought stress in sunflower (Helianthus annuus L.). - American Journal of Agricultural and Biological Sciences 5(1): 56-61.

[150] Soorninia, F., Toorchi, M., Norouzi, M., Shakiba, M. R. (2012): Evaluation of Sunflower Inbred Lines under Drought Stress. - Universal Journal of Environmental Research \& Technology 2(1): 70-76.

[151] Sourour, A., Afef, O., Mounir, R., Mongi, B. Y. (2017): A review: morphological, physiological, biochemical and molecular plant responses to water deficit stress. International Journal of Engineering Science 6(1): 2319-1805.

[152] Sreenivasulu, N., Sopory, S. K., Kishor, P. K. (2007): Deciphering the regulatory mechanisms of abiotic stress tolerance in plants by genomic approaches. - Gene 388(12): $1-3$

[153] Taiz, L., Zeiger, E. (2006): Plant Physiology (4th Edn). - Sinauer Associates, Massachusetts, $690 \mathrm{pp}$.

[154] Talaat, I. M., Gamal El-Din, K. M. (2007): Physiological Effect of Putrescine and Heat Hardening on Nigella sativa L. plants. - International Journal Agricultural Biology 7: 358-362.

[155] Tea, I., Genter, T., Naulet, N., Boyer, V., Lummerzheim, M., Kleiber, D. (2004): Effect of foliar sulfur and nitrogen fertilization on wheat storage protein composition and dough mixing properties. - Cereal Chemistry 81: 759-766.

[156] Tirani, M. M., Nasibi, F., Kalantari, K. M. (2013): Interaction of salicylic acid and ethylene and their effects on some physiological and biochemical parameters in canola plants (Brassica napus L.). - Photosynthetica 51(3): 411-8.

[157] Tohidi-Moghadam, H. R., Zahedi, H., Ghooshchi, F. (2011): Oil quality of canola cultivars in response to water stress and super absorbent polymer application. - Pesq. Agropec. Trop., Goiânia 41: 579-586.

[158] Triboi-Blondel, A. M., Renard, M. (1999): Effect of temperature and water stress on fatty acid composition of canola oil (Brassica napus L.). - Proceeding of the 10th International Canola congress, Australia: 82-87.

[159] Ullah, F., Bano, A. (2011): Effect of plant growth regulators on oil yield and biodiesel production of safflower (Carthamus tinctorius L.). - Brazilian Journal of Plant Physiology 23: 27-31.

[160] Ullah, F., Bano, A., Nosheen, A. (2012): Effect of plant growth regulators on growth and oil quality of canola (Brasica napus L.) under drought stress. - Pakistan Journal of Botany 44(6): 1873-1880.

[161] Vijayarengan, P., Abdul Jaleel, C., Chang-Xing, Z., Jayakumar, K., Azooz, M. M. (2009): Biochemical Variations in Groundnut under Cobalt Applications. - Global Journal of Molecular Sciences 4(1): 19-22.

[162] Yakhin, O. I., Lubyanov, A. A., Yakhin, I. A., Brown, P. H. (2017): Biostimulants in plant science: a global perspective. - Frontiers in Plant Science 7: 2049. doi.org/10.3389/fpls.2016.02049. 
[163] Zafar, S., Nasri, M., Moghadam, H. R., Zahedi, H. (2014): Effect of zinc and sulfur foliar applications on physiological characteristics of sunflower (Helianthus annuus L.) under water deficit stress. - International Journal of Bioscience 5(12): 87-96.

[164] Zahedi, H., Noor-Mohamadi, G. H., Shirani Rad, A. H., Habibi, D., Akbar, M., Boojar, M. (2009): The effects of zeolite and foliar applications of selenium on growth yield and yield components of three canola cultivars under drought stress. - World Applied Science Journal 7: 255-262.

[165] Zaidi, H., Waheed, A., Din, J. U., Arshad, M., Razzaq, A. (2015): Foliar application of salicylic acid reduced the harsh influences of water deficit and biochemical contents in varying degree in sunflower. - Sindh University Research Journal (Sci. Ser.) 47(4): 645648.

[166] Zaidi, H. E. S. (2015): Salicylic acid induced adaptive response of sunflower (helianthus annuus 1.) to drought stress. - Doctoral dissertation, Arid Agriculture University, Rawalpindi Pakistan.

[167] Zhang, X., Lu, G., Long, W., Zou, X., Li, F., Nishio, T. (2014): Recent progress in drought and salt tolerance studies in Brassica crops. - Breeding Science 64: 60-73. doi: 10.1270/jsbbs.64.60.

[168] Zhou, L. Y., Li, X. D., Tang, X., Lin, Y. J., Li, Z. F. (2007): Effects of different application amount of N, P, K fertilizers on physiological characteristics, yield and kernel quality of peanut. - The Journal of Applied Ecology 18(11): 2468-74. 